\title{
HAEMODYNAMIC MONITORING IN THE MANAGEMENT OF SEVERE PRE-ECLAMPSIA AND ECLAMPSIA
}

\author{
Stephen H. Rolbin, A.F.D. Cole and Ernest M. Hew
}

\begin{abstract}
Four case histories are presented to illustrate that haemodynamic monitoring is a useful guide in the acute management of severe pre-eclampsia and eclampsia. The application of intensive monitoring and therapy to patients in the delivery room is both feasible and of great help to the clinician managing fluid therapy and/or anaesthesia.
\end{abstract}

Key Words: Eclampsia, Pre-Eclampsia: haemodynamic monitoring, management.

PRE-ECLAMPSIA AND ECLAMPSIA of pregnancy are major causes of maternal mortality. The current incidence of pre-eclampsia in North America is five to seven per cent and that of eclampsia 0.7 to 0.1 per cent. ${ }^{1,2}$ Combined, they may cause 40 per cent of maternal deaths from obstetrical causes. ${ }^{3}$

Pre-eclampsia is classically defined as the development of hypertension associated with either proteinuria or oedema or both. ${ }^{4}$ It becomes severe if any one of the following signs or symptoms is present, ${ }^{5,6}$ viz; systolic blood pressure $21.28 \mathrm{kPa}$ (160torr) or greater; diastolic blood pressure $14.63 \mathrm{kPa}$ (110 torr) or greater; proteinuria five grams per day or greater; urine output $400 \mathrm{ml}$ or less per 24 hours; headache; visual disturbance; epigastric pain.

Pre-eclampsia becomes eclampsia when seizures occur. The foetal and maternal mortality associated with eclampsia far exceeds that of pre-eclampsia ${ }^{7}$ and thus active treatment of preeclampsia should improve the outcome for both.

Severe pre-eclampsia may have widespread consequences. ${ }^{8}$ Maternal consequences may be hypertension, cerebro-vascular accident, pulmonary oedema, haemoconcentration and blood volume depletion, coagulopathy, renal and hepatic dysfunction and drug interaction.

Stephen H. Rolbin, M.D.C.M. F.R.C.P.(C), CoDirector, Obstetrical Anaesthesia; A.F.D. Cole, M.D., F.R.C.P.(C), Co-Director, Obstetrical Anaesthesia; Enest M. Hew, M.D., F.R.C.P.(C) F.F.A.R.C.S.(I), Assistant Professor, Department of Anaesthesia, CoDirector, Intensive Care Unit; Mount Sinai Hospital, Toronto.

Address reprint requests to: Dr. Stephen H. Rolbin, Department of Anaesthesia, Mount Sinai Hospital, 600 University Avenue, Toronto, Ontario. M5G 1X5

Canad. Anaesth. Soc. J., vol. 28, no. 4, July 1981
Placental consequences may be insufficiency or abruptio plancentae. Consequences for the foetus may be intra-uterine death, the effects of premature labour, small size for gestational age and neonatal depression.

In addition to clinical evaluations, circulatory function should be monitored by following arterial blood pressure, electrocardiogram, central venous pressure or left atrial filling pressure and hourly urine output. The following cases highlight the feasibility of intensive haemodynamic monitoring of the patient and provide useful clinical information.

\section{Patient \#I}

A 32-year-old multipara was admitted at 36 weeks gestation because of increased blood pressure of $22.6 / 13.3 \mathrm{kPa}$ (170/100 torr) hyperreflexia, pretibial oedema and $4+$ proteinuria. Her haemoglobin was $11.2 \mathrm{~g}$, platelet count 325,000 per $\mathrm{mm}^{3}$, serum sodium $128 \mathrm{mmol} / \mathrm{l}$, potassium 4.4 $\mathrm{mmol} / \mathrm{l}$, chloride $100 \mathrm{mmol} / \mathrm{l}$, BUN $14 \mathrm{mg} / \mathrm{dl}$ and creatinine $0.9 \mathrm{mg} / \mathrm{dl}$. Despite bedrest for two days her blood pressure rose to $22.6 / 14.6 \mathrm{kPa}$ (200/110 torr). On arrival in the delivery room, diazepam $10 \mathrm{mg}$ was given orally. A bolus of five grams of magnesium sulphate was given intravenously and a continuous infusion of one gram per hour was started. A Foley catheter was also inserted. Hydralazine (Apresoline ${ }^{\circledR}$ ) $5 \mathrm{mg}$ and then $10 \mathrm{mg}$ was given intravenously when her diastolic blood pressure exceeded $14.63 \mathrm{kPa}$ ( 110 torr). The electrocardiogram was monitored continuously.

A balloon-floatation thermodilution catheter (Swan-Ganz) was inserted at the bedside. Cardiac output and other haemodynamic indices 363 
TABLE I

Haemodynamic Indices Normal Non-Pregnant Values*

\begin{tabular}{lcc}
\hline & Range & Average \\
\hline Pulmonary Capillary Wedge Pressure $\mathrm{kPa}$ (torr) & $0.6-1.73(4.5-13)$ & $1.2(9)$ \\
Pulmonary Artery Pressure $\mathrm{kPa}$ (torr) & & \\
$\quad$ Systolic & $2.26-4.26(17-32)$ & $3.33(25)$ \\
$\quad$ Diastolic & $0.53-1.73(4-13)$ & $1.20(9)$ \\
Cardiac Index $\left(1 / \mathrm{min} \cdot \mathrm{m}^{2}\right)$ & $2.1-4.9$ & 3.5 \\
Left Ventricle Work $\left(J o u l e s / \mathrm{min} \cdot \mathrm{m}^{2}\right)$ & $36.3-63.7$ & 50.0 \\
Total Systemic Resistance $\left(\right.$ Dynes sec $\left./ \mathrm{cm}^{5} \cdot \mathrm{m}^{2}\right)$ & $774-1486$ & 1130 \\
Total Pulmonary Resistance (Dynes sec/ $\left./ \mathrm{cm}^{5} \cdot \mathrm{m}^{2}\right)$ & $103-307$ & 205 \\
\hline
\end{tabular}

* Indexed to body surface area.

TABLE II

Haemodynamic Assessment* (Patient \#1)

\begin{tabular}{|c|c|c|c|c|}
\hline & $\begin{array}{l}\text { Initial } \\
\text { Values }\end{array}$ & $\begin{array}{l}\text { After Fluid } \\
\text { Before } \\
\text { Section }\end{array}$ & $\begin{array}{c}\text { During Anaes. } \\
\text { Before } \\
\text { Delivery }\end{array}$ & $\begin{array}{c}2 \text { Hours } \\
\text { Post-partum }\end{array}$ \\
\hline $\begin{array}{r}\text { Blood Pressure } \\
\text { (torr) }\end{array}$ & $\begin{array}{l}26.6 / 14.6 \\
(200 / 110)\end{array}$ & $\begin{array}{l}18.6 / 10.6 \\
(140 / 80)\end{array}$ & $\begin{array}{l}14.6 / 10.6 \\
(110 / 80)\end{array}$ & $\begin{array}{c}16 / 9.3 \\
(120 / 70)\end{array}$ \\
\hline Heart Rate (beats/min) & 130 & 130 & 90 & 100 \\
\hline Pulmonary Capillary Wedge Pressure kPa (torr) & $0.266(2)$ & $0.67(5)$ & $1.6(12)$ & $1.33(10)$ \\
\hline \multicolumn{5}{|c|}{ Pulmonary Artery Pressure kPa (torr) } \\
\hline Systolic & - & $1.6(12)$ & $2.66(20)$ & $2.31(18)$ \\
\hline Diastolic & - & $1.06(8)$ & $2.26(17)$ & $1.86(14)$ \\
\hline Cardiac Output $(1 / \mathrm{min})$ & - & 12.1 & 7.7 & 10.5 \\
\hline Cardiac Index $\left(1 / \mathrm{min} \cdot \mathrm{m}^{2}\right)$ & - & 7.1 & 4.5 & 6.0 \\
\hline Left Ventricle Work (Joules/min $\cdot \mathrm{m}^{2}$ ) & - & 123.6 & 57.9 & 89.2 \\
\hline Total Systemic Resistance (Dynes $\mathrm{sec} / \mathrm{cm}^{5} \cdot \mathrm{m}^{2}$ ) & - & 372 & 493 & 367 \\
\hline Total Pulmonary Resistance (Dynes $\mathrm{sec} / \mathrm{cm}^{5} \cdot \mathrm{m}^{2}$ ) & - & 35 & 107 & 67 \\
\hline
\end{tabular}

* Indexed to body surface area.

were measured. ${ }^{9}$ Normal haemodynamic indices in the non-pregnant patient are shown in Table I. The initial pulmonary capillary wedge pressure was $0.266 \mathrm{kPa}$ ( 2 torr) (Table II). This increased to $0.65 \mathrm{kPa}$ (5 torr) after infusion of $1,000 \mathrm{ml}$ of Normosol-RD and $500 \mathrm{ml}$ of normal saline over 20 minutes. At this time, it was elected to proceed with a primary caesarean section. General anaesthesia was chosen. A live female infant $(2183 \mathrm{~g})$ was delivered. The Apgar scores were nine at one and five minutes. At birth umbilical artery $\left[\mathrm{H}^{+}\right]$ was $56.23 \mathrm{nmol} / 1(\mathrm{pH} 7.25), \mathrm{PCO}_{2} 4.66 \mathrm{kPa}(35$ torr) $\mathrm{Po}_{2} 3.86 \mathrm{kPa}$ (29 torr) and bicarbonate 20 $\mathrm{mmol} / \mathrm{l}$.

During the operation, which took one hour, the patient received $2300 \mathrm{ml}$ of normal saline and $500 \mathrm{ml}$ of Normosol-RD and the blood pressure remained stable. The pulmonary capillary wedge pressure rose from $0.66 \mathrm{kPa}$ ( 5 torr) before anaesthesia to $1.6 \mathrm{kPa}$ (12 torr) at the end of operation. The estimated blood loss was $800 \mathrm{ml}$.

She was transferred to the intensive care unit where she had an uneventful postoperative course.

\section{Patient \#2}

A 30-year-old multipara was admitted at 31 weeks gestation because of pre-eclampsia and decreasing urine oestriols. Her blood pressure was maintained at $21.6 / 13.3 \mathrm{kPa}$ (160/100 torr) but on the 14th hospital day she convulsed. An oral airway was inserted and supplemental oxygen started. She was given diazepam $10 \mathrm{mg}$ and magnesium sulphate $4.0 \mathrm{~g}$ intravenously.

On admission to the delivery room she was drowsy and her blood pressure was 21.6/14.36 $\mathrm{kPa}(160 / 108$ torr). Her haemoglobin was $12.7 \mathrm{~g}$, sodium $138 \mathrm{mmol} / 1$, potassium $4.0 \mathrm{mmol} / 1$, chloride $101 \mathrm{mmol} / \mathrm{l}$, bicarbonate $28 \mathrm{mmol} / \mathrm{l}, \mathrm{BUN}$ $16 \mathrm{mg} / \mathrm{dl}$, creatinine $1.0 \mathrm{mg} / \mathrm{dl}$ and creatinine clearance $75 \mathrm{ml} / \mathrm{min}$. Her platelet count was 26,000 per $\mathrm{mm}^{3}$. Other coagulation studies were normal. Her SGOT was 350 units, SGPT 433 units and LDH 1432 units. 
TABLE III

Haemodynamic Assessment (Patent \#2)

\begin{tabular}{|c|c|c|c|}
\hline & $\begin{array}{c}\text { Initial } \\
\text { Assessment } \\
\text { After } \\
\text { Drug Therapy }\end{array}$ & $\begin{array}{l}90 \text { Minutes } \\
\text { Later }\end{array}$ & $\begin{array}{l}24 \text { Hours } \\
\text { Post-partum }\end{array}$ \\
\hline $\begin{array}{r}\text { Blood Pressure } \mathrm{kPa} \\
\text { (torr) }\end{array}$ & $\begin{array}{c}20 / 12 \\
(150 / 90)\end{array}$ & $\begin{array}{l}21.3 / 13.3 \\
(160 / 100)\end{array}$ & $\begin{array}{l}21.3 / 11.3 \\
(160 / 85)\end{array}$ \\
\hline Heart Rate (beats/min) & 90 & 105 & 110 \\
\hline $\begin{array}{l}\text { Pulmonary Capillary Wedge Pressure } \mathrm{kPa} \text { (torr) } \\
\text { Pulmonary Artery Pressure } \mathrm{kPa} \text { (torr) }\end{array}$ & $0.53(4)$ & $0.4(3)$ & $1.2(9)$ \\
\hline $\begin{array}{l}\text { Systolic } \\
\text { Diastolic }\end{array}$ & $\begin{array}{l}1.2(9) \\
0.53(4)\end{array}$ & $\begin{array}{l}1.2(9) \\
0.53(4)\end{array}$ & $\begin{array}{l}2.4(18) \\
1.6(12)\end{array}$ \\
\hline Cardiac Output (1/min) & 8.1 & 8.3 & 9.5 \\
\hline Cardiac Index $\left(1 / \mathrm{min} \cdot \mathrm{m}^{2}\right)$ & 4.3 & 4.5 & 5.1 \\
\hline Left Ventricle Work (Joules $/ \mathrm{min} \cdot \mathrm{m}^{2}$ ) & 85.3 & 94.1 & 102.0 \\
\hline Total Systemic Resistance (Dynes $\mathrm{sec} / \mathrm{cm}^{5} \cdot \mathrm{m}^{2}$ ) & 580 & - & - \\
\hline Total Pulmonary Resistance (Dynes $\mathrm{sec} / \mathrm{cm}^{5} \cdot \mathrm{m}^{2}$ ) & 29 & 29 & 63 \\
\hline
\end{tabular}

During the first hour she required three intravenous doses of hydralazine $2.5 \mathrm{mg}$ each to keep the diastolic blood pressure below $14.6 \mathrm{kPa}$ (110 torr). Hourly urine output was monitored. A Swan-Ganz catheter was inserted at the bedside. She received $2900 \mathrm{ml}$ of Normosol-RD, and 250 $\mathrm{ml}$ of Normosol-MD in the first three hours. Despite this fluid load the pulmonary capillary wedge pressure was only $0.53 \mathrm{kPa}$ (4torr) and blood pressure $20 / 12 \mathrm{kPa}$ (150/90 torr) with a pulse rate of 90 beats/minute. A haemodynamic profile 90 minutes later showed similar values (Table III).

It was decided to allow vaginal delivery and labour was induced. After $6 \frac{1}{2}$ hours, labour had failed to progress and moderate variable decelerations were present with each contraction. Consequently caesarean section was done under general anaesthesia.

During the six hours preceding caesarean section she had received $5800 \mathrm{ml}$ of Normosol-RD, $250 \mathrm{ml}$ Normosol-MD and $100 \mathrm{ml}$ of five per cent dextrose. Before induction of general anaesthesia her blood pressure was $18.6 / 10.6 \mathrm{kPa}(140 / 80$ torr) heart rate 110 beats per minute and pulmonary capillary wedge pressure was $1.6 \mathrm{kPa}(12$ torr). The blood pressure was stable before delivery, but fell to $12 / 8 \mathrm{kPa}$ (90/60torr) for approximately five minutes immediately after. She received $1,000 \mathrm{ml}$ of Normosol-RD, one unit of packed cells and one unit of fresh frozen plasma during the anaesthetic. Her postoperative course was uneventful.

The infant weighed 1120 grams. Apgar scores were seven and eight at one and five minutes.
Umbilical artery $\left[\mathrm{H}^{+}\right]$was $38.02 \mathrm{nmol} / \mathrm{l}(\mathrm{pH} 7.42)$, $\mathrm{PCO}_{2} 6.92 \mathrm{kPa}$ (52 torr), $\mathrm{PO}_{2} 2.26 \mathrm{kPa}$ (17 torr) and bicarbonate $21 \mathrm{mmol} / 1$. At ten minutes of age the infant became apnoeic. Treatment included intubation and ventilation with $5 \mathrm{~cm} \mathrm{H}_{2} \mathrm{O}$ continuous distending airway pressure. Transient mild respiratory distress syndrome developed. The infant was discharged home in good condition after an uneventful course in a neonatal intensive care unit.

\section{Patient \#3}

A 23-year-old primipara was admitted to labour at 36 weeks gestation. She had hyperactive reflexes, $3+$ proteinuria and blood pressure of $21.6 / 14.6 \mathrm{kPa}$ (160/110 torr). Magnesium sulphate was started and hourly urine output was monitored. Laboratory investigations were normal and continuous lumbar epidural analgesia was instituted using $10 \mathrm{ml}$ of bupivacaine 0.25 per cent. Hypertension persisted at $21.6 / 14.6 \mathrm{kPa}(160 / 110$ torr) despite adequate pain relief. Hydralazine $20 \mathrm{mg}$ was given intravenously. The blood pressure fell to $16 / 10.6 \mathrm{kPa}$ (120/80 torr). A SwanGanz catheter and an arterial line were inserted. At this time the pulmonary capillary wedge pressure was $0.266 \mathrm{kPa}$ ( 2 torr) (Table IV). This increased to $1.33 \mathrm{kPa}$ (10torr) after infusion of $200 \mathrm{ml}$ of 25 per cent albumin.

A decision was made to do a caesarean section because of failure of labour to progress. She had received $1250 \mathrm{ml}$ of normal saline, $400 \mathrm{ml}$ of dextrose five per cent and $200 \mathrm{ml}$ of 25 per cent albumin. At this time per pulmonary capillary wedge pressure was $0.66 \mathrm{kPa}$ ( 5 torr) and her 


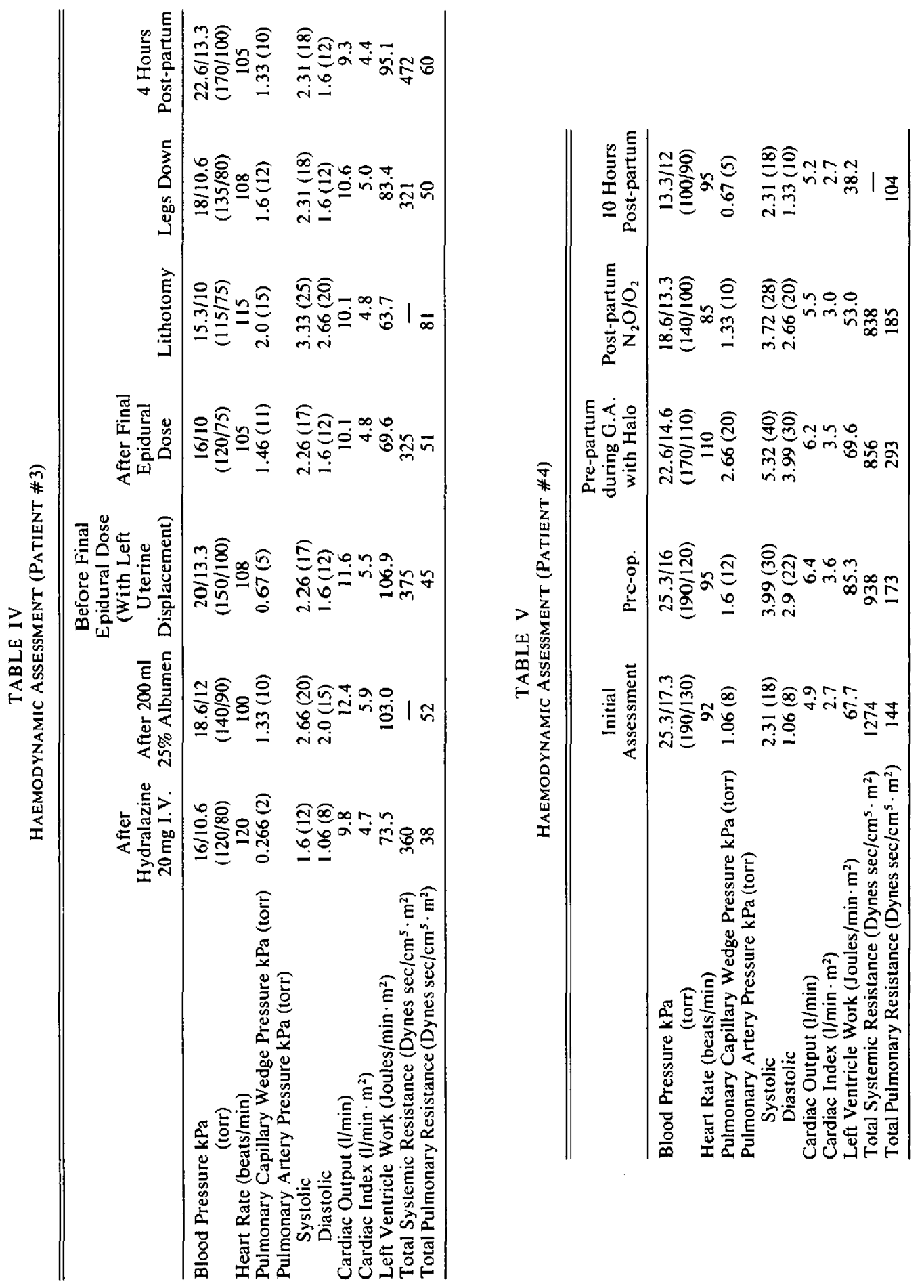


blood pressure $20 / 13.3 \mathrm{kPa}$ (150/100torr). A single epidural injection of $30 \mathrm{ml}$ carbonated lidocaine two per cent was given. The haemodynamic indices remained stable. A vaginal examination was then done. It was felt that this patient could be delivered vaginally by forceps and accordingly this was done.

The infant weighed 1800 grams and Apgar scores were seven and nine at one and five minutes. The umbilical artery $\mathrm{Po}_{2}$ was $1.46 \mathrm{kPa}$ (11 torr), $\mathrm{PCO}_{2}$ was $7.32 \mathrm{kPa}$ (55 torr), $\left[\mathrm{H}^{+}\right]$ $63.1 \mathrm{nmol} / \mathrm{l}(\mathrm{pH} 7.20)$ and bicarbonate $20 \mathrm{mmol} / \mathrm{l}$. Umbilical venous $\mathrm{Po}_{2}$ was $2.13 \mathrm{kPa}$ (16 torr), $\mathrm{PCO}_{2}, 6.78 \mathrm{kPa}$ (51 torr) $\left[\mathrm{H}^{+}\right] 61.66 \mathrm{nmol} / \mathrm{l}(\mathrm{pH}$ 7.21) and bicarbonate $20 \mathrm{mmol} / \mathrm{l}$.

Post partum the mother's blood pressure remained at $20 / 14.6 \mathrm{kPa}$ (150/110 torr) and she was started on propanolol $40 \mathrm{mg}$ four times daily.

\section{Patient \#4}

A 33-year-old primigravida was admitted at 34 weeks gestation. She complained of epigastric pain. Her blood pressure on admission was $23.3 / 14.6 \mathrm{kPa}$ (175/110torr), reflexes were increased and there was $2+$ protein in the urine. She had been receiving methyldopa $250 \mathrm{mg}$ twice daily for two weeks before admission.

She was given $250 \mathrm{mg}$ of methyldopa orally and $4 \mathrm{~g}$ of magnesium sulphate intramuscularly followed by a continuous infusion of one gram per hour. The blood pressure decreased to 21.3/13.97 $\mathrm{kPa}(160 / 105$ torr $)$.

Laboratory investigations were all normal except for the platelet count of 120,000 per $\mathrm{mm}^{3}$. Six hours after admission the patient complained of increasing upper abdominal pain and her blood pressure rose to $23.9 / 15.3 \mathrm{kPa}$ (180/115 torr). A Swan-Ganz catheter was inserted.

A decision was made to do a caesarean section because of difficulty in maintaining a stable blood pressure. In the eight hours preceeding caesarean section the patient received one litre of Normosol-RD and $1150 \mathrm{ml}$ of 3.3 per cent dextrose and 0.3 per cent normal saline solution. Immediately before operation her blood pressure rose to $25.27 / 15.96 \mathrm{kPa}(190 / 120$ torr $)$ and the wedge pressure was $1.6 \mathrm{kPa}$ (12 torr). Cardiac output had risen from $4.9 \mathrm{l} / \mathrm{min}$ to $6.4 \mathrm{l} / \mathrm{min}$ (Table V).

The patient was pre-oxygenated for five minutes and received a further $700 \mathrm{ml}$ of Normosol-RD. General anaesthesia was induced. Blood pressure was $22.6 / 14.6 \mathrm{kPa}$ (170/110 torr) before delivery, and rose transiently to $29.26 / 15.96 \mathrm{kPa}$
(220/120 torr) immediately after and returned to $18.6 / 13.3 \mathrm{kPa}(140 / 100$ torr) by 11 minutes postpartum. The haemodynamic data are shown in Table V. The patient received $2700 \mathrm{ml}$ of balanced salt solution before delivery.

The infant weighed 2012 grams and the Apgar scores were three and eight at one and five minutes. The baby responded to positive ventilation by mask within two to three minutes. Umbilical arterial blood $\left[\mathrm{H}^{+}\right]$was $58.88 \mathrm{nmol} / 1 \mathrm{l}(\mathrm{pH}$ 7.23), $\mathrm{PCO}_{2} 6.25 \mathrm{kPa}$ (47 torr), bicarbonate 22 $\mathrm{mmol} / \mathrm{l}$ and base excess -6 . Umbilical venous $\left[\mathrm{H}^{+}\right]$was $52.48 \mathrm{nmol} / \mathrm{l}(\mathrm{pH} 7.28), \mathrm{PCO}_{2} 5.45 \mathrm{kPa}$ (41 torr) $\mathrm{Po}_{2} 3.33 \mathrm{kPa}$ (25 torr), bicarbonate 19 $\mathrm{mmol} / \mathrm{l}$ and base excess -7 .

The infant did well.

Post partum the mother was given methyldopa $250 \mathrm{mg}$ twice daily.

\section{Discussion}

The authors believe that the anaesthetists should be notified as soon as any critically ill patient arrives in the delivery room. Preeclampsia and eclampsia is but one of these situations. Their skills and experience with fluid management and pain control are useful in the treatment and monitoring of these patients.

The aim of monitoring patients were severe pre-eclampsia or eclampsia is early detection of complications in mother and foetus. This minimizes the risks of both. Blood pressure must be measured frequently and an arterial line is useful. Deep tendon reflexes are used as a guide to magnesium therapy. Hyper-reflexia indicates impending seizures and a need for more magnesium. Decreased reflexes indicate an excessive serum magnesium level. One must remember that epidural anaesthesia may alter knee or ankle reflexes, ${ }^{10}$ and thus the biceps reflex is more reliable. Maternal ventilation should also be monitored as magnesium intoxication may cause muscle weakness. Maternal sedation may further decrease adequacy of ventilation. Frequent serial vital capacity determination will detect early muscle fatigue. " A Foley catheter is essential for measurement of hourly urine output.

Monitoring of the severe pre-cclamptic should also include a central venous pressure line, since many of these patients are significantly volume depleted. ${ }^{12-15}$ A Swan-Ganz catheter is a useful guide to the infusion of large volumes of fluid over a short period of time, since pulmonary 
oedema may develop due to cardiogenic or other causes. ${ }^{2,15-17}$ Swan-Ganz catheterization, however, can be done safely only in the delivery suite by an experienced team.

The four cases reported illustrate the haemodynamic changes associated with pre-eclampsia. ${ }^{13,14,16}$ Previous studies ${ }^{12,18,19}$ have demonstrated marked differences in haemodynamic indices of normotensive and hypertensive pregnant patients. The hypertensive patient also has a higher total peripheral resistance and a decreased plasma volume. ${ }^{12-15}$ These indices are subject to rapid and frequent changes as a result of medical therapy and/or anaesthesia. In particular induction of anaesthesia, whether regional or general, may cause profound haemodynamic changes.

Monitoring of the pulmonary capillary wedge pressure allows accurate and immediate assessment of the patient's fiuid requirements. The four cases are presented to illustrate this. Insertion of a Swan-Ganz catheter can be done by the bedside in the delivery room.

We believe that all patients with severe preeclampsia should have cardiac filling pressures monitored. In many patients the central venous pressure (CVP) (right heart filling pressure) would be adequate because it accurately reflects the haemodynamics of the left side of the heart. However, the CVP is not always reliable because of the possibility of non-cardiogenic pulmonary oedema. ${ }^{315-17}$ There are not enough data in our series for useful comparison of the CVP and pulmonary capillary wedge pressure. We maintain that rapid infusion of large volumes of fluids may cause significant morbidity and should be closely monitored. We aim for a pulmonary capillary wedge pressure of $1.33 \mathrm{kPa}$ (10 torr) before induction of anaesthesia for caesarean section.

Hodgkinson and coworkers ${ }^{20}$ recently compared systemic and pulmonary blood pressure during caesarean section in hypertensive parturients. Hodgkinson cautioned (and we agree) against using the small number of cases reported to draw any conclusion as to the relative safety of general and epidural anaesthesia. Enough information is not yet available.

Patients with pre-eclampsia and eclampsia of pregnancy offer a major challenge to the perinatal team. Continuous co-operation of obstetricians, anaesthetists, neonatologists and nurses is required to improve maternal and neonatal outcome.

\section{REFERENCES}

1. Zuspan, F.P. Toxemia of Pregnancy. J. Reprod. Med. 2. 116 (1969).

2. Marx, G.F. \& Wang, C.N. Anesthetic Considerations in Hypertensive Disorders of Pregnancy. Current Problems in Anesthesia and Crit. Care Med. I: 1978, p. 17.

3. GibBs, C.E. \& Locke, W.E. Maternal deaths in Texas, 1969 to 1973: A report of 501 consecutive deaths from the Texas Medical Association's Committee on Maternal Health. Am. J. Obs. Gyn. 126: 687 (1976).

4. Obstetrics - Gynecologic Terminology, Hughes E.C. (ed), F.A. Davis Co., Philadelphia: 1972.

5. MarX, G.F.\& WANG, C.N. Anesthetic Consideration in Hypertensive Disorders of Pregnancy. Current Problems in Anesthesia in Critical Care Medicine I: 1978, p. 6.

6. Definitions and Classifications in Williams Obstetric 15 ed. Pritchard J.A. and MacDonald P.C. (ed) New York, Appleton-Century-Crofts, 1976, pp. 551-553.

7. Treatment of Eclampsia in Williams Obstetrics 15 ed. Pritchard J.A. and MacDonald P.C. (ed) New York, Appleton-Century-Crofts, 1976, pp. 571577.

8. Studd, J. Pre-eclampsia. Brit. J. Hosp. Med. 18 (1): $52(1977)$

9. Forrester, J.S., Ganz, W., Diamond, G. et al. Thermodilution cardiac output determination with a single flow directed catheter. Am. Heart J. 83: 306 (1972).

10. Epidural Analgesia, Bromage P.R. (ed), W.B. Saunders Co., Philadelphia, 1978, p. 148.

11. Rolbin, S.H., Levinson, G., SNider, S.M. et al Anesthetic Considerations for Myasthenia Gravis and Pregnancy. Anes. Analg. 57: 441 (1978).

12. SMITH, R.W. Cardiovascular Alterations in Toxemia. Am. J. Obstet. Gynecol. 107: 979 (1970).

13. Joyce, III, T.H., Debnath, K.S. \& Baker, E.A Pre-eclampsia - Relationship of CVP and Epidural Analgesia in Abstracts of Scientific Papers, 1979, Annual Meeting of the American Society of Anesthesiologists, San Francisco, Calif. Anesthesiology 51: S297 (1979).

14. Paust, J.C. \& Reddy, M.A. Swan-Ganz Catheterization - An Aid in Management of High Risk Obstetrical Patients. J. of the Kentucky Medical Association 76: 319 (1978).

15. Stauss, R.G., Keefer, R., Burke, T. el al. Acute Pulmonary Edema in the Obstetrical Patient: The Use of Hemodynamic Monitoring. In Abstracts of Scientific Papers, 1979 Society of Critical Care Medicine, San Francisco, California p. 75.

16. Freund, U., French, W., Carlson, R.W. et al. Hemodynamic and metabolic studies of a case of toxemia of pregnancy. Am. J. Obstet. Gynecol. 127: 206 (1977).

17. Lopez-Lira, M., Rubio Linares, G. \& HernanDEz HORTA, J.L. Maternal Mortality rates in eclampsia. Am. J. Obstet. Gynecol. 124: 149 (1976).

18. Maternal Physiologic Alterations During Pregnancy in Anesthesia for Obstetrics, Shnider, S.M. and Levinson, G. (ed) Baltimore, Williams and Wilkins, 1979, pp. 3-11. 
19. Lim, Y.L. \& Walters, W.A.W.: Haemodynamics of Mild Hypertension in Pregnancy. Br. J. Obs. Gyn. 86: 198 (1979).

20. Hodgkinson, R., husain, F.J. \& HaYsahi,
R.H.: Systemic and Pulmonary Blood Pressure During Caesarean Section in Parturients with Gestational Hypertension. Canad. Anaesth. Soc. J. 27: 389 (1980).

\section{RÉSUMÉ}

Quatre observations sont présentées dans le but d'illustrer que le monitorage hémodynamique peut-être utile au traitement de la pré-éclampsie grave et de l'éclampsie. L'application d'un traitement intensif guidé par un monitorage adéquat à des patientes en salle d'accouchement est réalisable et peut être d'un grand secours dans la conduite de la thérapie liquidienne et/ou de l'anesthésie. 